Schmerzhafte Knoten an der seitlichen Rumpfwand

\title{
Woher stammen die roten Papeln und Pusteln?
}

\section{Anamnese}

Der 55-jährige Patient stellt sich mit seit zwei Monaten rezidivierend auftretenden Hauterscheinungen an der seitlichen Rumpfwand und an den Beinen vor (Abb. 1). Außerdem bestünden axillär kirschkerngroße Knoten, die schmerzhaft seien.

Wie lautet Ihre Verdachtsdiagnose?

Zur Auflösung bitte umblättern

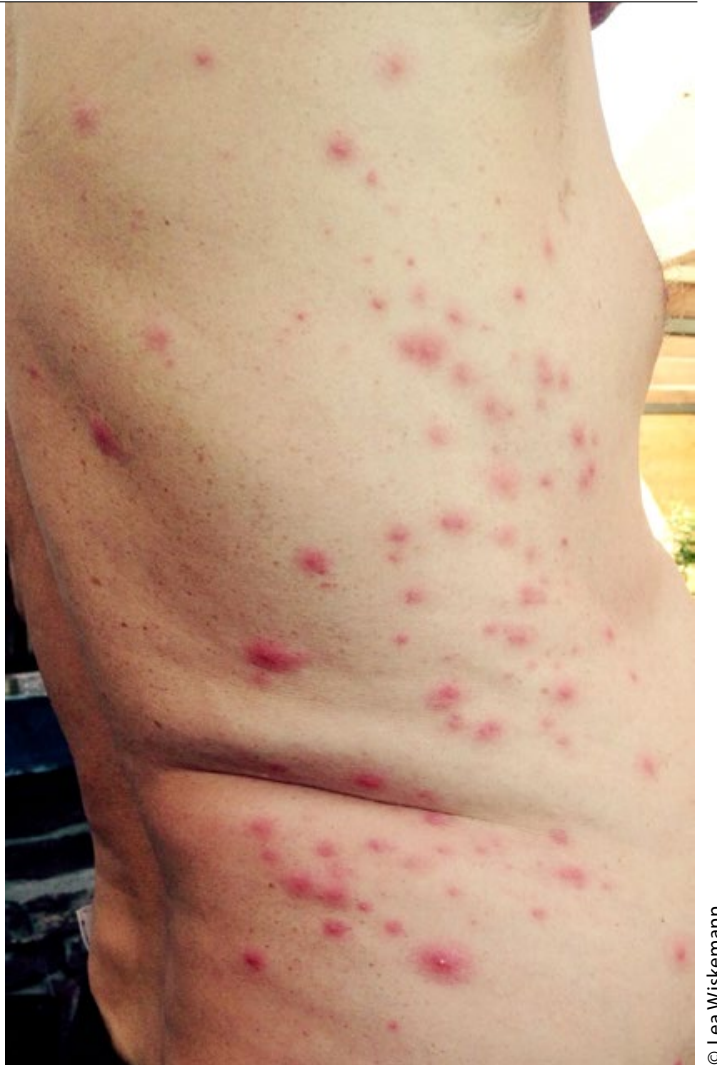

Abb. 1: flankenbetont symmetrisch verteilte, rötliche Maculae, Papeln und Pusteln

\section{Blickdiagnosen auf springermedizin.de}

Weitere Fälle, bei denen Ihr diagnostischer Spürsinn gefragt ist, stehen für Sie online in der Rubrik „Blickdiagnose interaktiv“ bereit: www.springermedizin.de/blickdiagnose-interaktiv

Eine Sammlung interessanter Kasuistiken aus der Praxis finden Sie außerdem im Dossier „Blickdiagnosen aus der Praxis”: www.springermedizin.de/307330 